\title{
Marginalisation Of Women In Agriculture: A Study Of Soura Tribe In Gajapati District
}

\author{
Dr. Urmimala Das ${ }^{1}$, Director, and Junas Sabar ${ }^{2}$, Ph.D Scholar, WSRC, \\ Berhampur University, Odisha
}

\begin{abstract}
This paper emphasizes on the present situation of women in agriculture and suggests possible roadmaps to mainstream women in development process. Women's contribution in any economy is inevitable. Their roles vary region to region, work to work, state to state, and country to country. Women are agricultural labour forces and marginalized workers. They participate in many aspects of rural life - in paid employment, trade and marketing, as well as many unpaid activities, such as tending animals, collecting water and wood for fuel, and caring for family members. Women are the backbone of agricultural workforce in the country. In the world women are the engine of agricultural workforce; but worldwide her hard work has mostly been remained unpaid (DARE: 2003). Women play a vital role in advancing agricultural development and food security (FAO: 2011). They participate in many aspects of rural life - in paid employment, trade and marketing as well as many unpaid activities, such as tending animals, collecting water and wood for fuel and caring for family members. Women also manage household consumption and food preparation (Doss etal: 2008)'
\end{abstract}

Keyword: Marginalisation, Cultivator, Agricultural labourer, Livelihood, Subsistence earning, Soura Women.

Agriculture is the back bone of many developing countries. Women account for more than half of the work force by participating in different activities either directly or indirectly. The gender division of labour varies from one society and culture to another and within each culture external circumstances influence the level of activity (Nigist: 2004). Agriculture is an engine of economic growth and provides the basis for most livelihoods in developing countries (World Bank: 2007). Women are the unavoidable part of any development programmes whether it is for developed or developing country (Chauhan, J: 2015). Odisha is one of the poorest states in India, with an estimated $47 \%$ of its population living on less than a dollar a day (Haans \& Dubey: 2003). A regional and social group-wise analysis of poverty in Odisha highlights the fact that the population in scheduled areas is comparatively much poorer than the population in non-scheduled areas, and that scheduled tribes are the poorest groups (Kumar Kundan: 2005). Odisha is primarily agrarian economy, its main workforce as primarily engaged are agriculture and its related activities.

The 'Sabaras' are the fourth largest tribal community in Odisha, after Kondhs, Gonds and Santhals. The Sabaras are known by different names in different parts of Odisha as Saura, Soura, Savara or Sahara. In their own language they call themselves "Sora" and their language "sora langam". The Sabaras are classified into two types; Lanjia Sabars and Sarada Sabaras. The Sabara are not accustomed to settle land cultivation and most of these tribals in the interior area still have settled land cultivation, which are provided by the Government by clearing the forest (Mohanty, S.C. \& Paikaray, B.K.). Women have played and continue to play a key role in the conservation of basic life support systems such as land, water, flora and fauna (Prasad C: 1992). Women play a central role in the agriculture economy (Chauhan, $J: 2015$ ). Even cultural anthropological literature suggests that agriculture is invention of women. Farming in India is mainly a family occupation (Chauhan, N.M: 2011). As farmers, agricultural labours and entrepreneurs, women constitute the backbone of India's agricultural and rural economy (Patel A: 2012). Women constitute half of the agricultural labour force in low-income countries (FAO: 2011). Women's role is of multi-dimensional in nature; agricultural fields need sowing, transplanting, weeding, irrigation, fertilizer application, plant protection, harvesting, winnowing, storing etc. In domestic field her responsibility encompasses cooks, child rearing, water collection, fuel wood gathering, household maintenance etc and last allied activity fields- cattle management, fodder collection, milking. Most low-income women in developing countries live and work in rural areas and agriculture is their primary source of employment. They produce both food and cash crops and have multiple and diverse roles. They work in their own plots and those of others, they work as unpaid or paid workers, employers, employees and as wage labuorers in both on and of farm enterprises (Bosesrup, E: 1970).

In Gajapati district of Odisha, percentage of women cultivators are declining from 27.5 to 13.7 percent between 2001 to 2011 and women's agricultural labourer are increasing rapidly from 57.7 in 2001 to 66.3 percentage in Census 2011. It further marginalises women in the district. Women's lower and discriminated wages than men 
is a crucial aspect of increased gendered appropriation of surplus value by landlords. Agriculture and income from agricultural activity is linked to control over land. Land is the most productive asset but evidence suggests that its ownership is heavily skewed in favour of men and large business (Hans Asha: 2014).

Table. No.1-All Cultivators in 2001-2011

\begin{tabular}{|c|c|c|c|c|c|c|}
\hline \multicolumn{9}{|c|}{ All Cultivators in 2001-2011 } \\
\hline Years & \multicolumn{2}{|c|}{ India } & \multicolumn{2}{c|}{ Odisha } & \multicolumn{2}{c|}{ Gajapati } \\
\hline $2001-11$ & Male & Female & Male & Female & Male & Female \\
\hline $\begin{array}{c}2001 \\
\text { (Cultivators) }\end{array}$ & 31.06 & $\mathbf{3 2 . 9 3}$ & 34.2 & $\mathbf{2 0 . 1}$ & 37.4 & $\mathbf{2 7 . 5}$ \\
\hline $\begin{array}{c}2011 \\
\text { (Cultivators) }\end{array}$ & 24.9 & $\mathbf{2 4}$ & 28.4 & $\mathbf{1 2 . 9}$ & 29.6 & $\mathbf{1 3 . 7}$ \\
\hline
\end{tabular}

(Source: Census of India 2011 final data, Registrar General of India), Databook for PC: $4^{\mathrm{TH}}$ Aug-2014. Census of India 2011, Primary Census Abstract Figure at a Glance India.

Figure-1-All Cultivators in 2001-2011

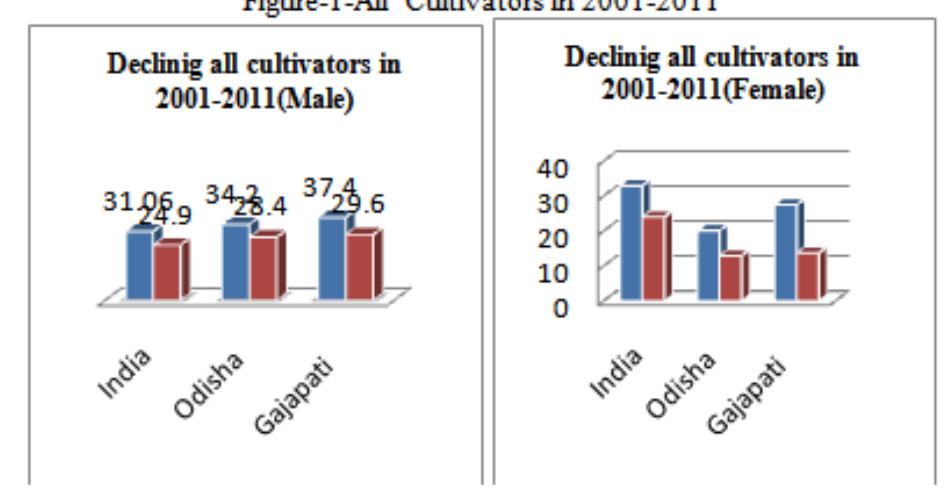

Overall picture shows men and women cultivators have declined and the percentage of agricultural labourer has increased between 2001 to 2011 both at all India, Odisha and also in the district of Gajapati. But the declining of women is more steep in case of cultivator at these three levels within last decade. It all shows the percentage of agricultural labourer among women is always much higher than that of men in India, Odisha and Gajapati district level. This also shows the marginalisation of women as agricultural labourer is much higher in the district of Gajapati in comparison to state and all India level data. As Gajapati district is the den of Soura people, it is obvious to conclude that Soura women are much more marginalised as agriculture labourers because it is the only source of earning for these unskilled Soura women.After looking to the marginalisation figure of women labourer in India, Odisha and Gajapati district; when we observe the high degree of concentration of women population in agriculture sector. Odisha and Gajapati district are primarily agrarian in character. The involvement of men and women in agricultural sector will provide some limelight on the gender disaggregated data in agrarian sector. People are engaged less as cultivators and more as agricultural labourer. A comparative data of agricultural labourers is shown in table- 2 \& figure- 2 between 2001 to 2011 Census. This table gives us indicators of men and women in this sector. Those tables show a gives comparative figures of agriculture sector at all India, Odisha and Gajapati district level, show the concentration of women are more among agricultural labourer. Agricultural labourer among men was 20.85 percent in 2001 in India which has increased to 38.87 in 2011. Among men this percentage has increased around 18 percent between 2001 to 2011.

Table. No. 2- All Agri-Labourers 2001-2011

\begin{tabular}{|l|l|l|l|l|l|l|}
\hline \multicolumn{7}{|c|}{ All Agri-Labourers 2001-2011 } \\
\hline years & \multicolumn{2}{|c|}{ India Agri-Labourers } & \multicolumn{2}{l|}{ Odisha Agri- } & \multicolumn{2}{l|}{$\begin{array}{l}\text { Gajapati } \\
\text { Labourers }\end{array}$} \\
\hline $2001-11$ & Male & Female & Male & Female & Male & Female \\
\hline $\begin{array}{l}2001 \text { (Agri- } \\
\text { Labourers) }\end{array}$ & 20.85 & 24.9 & 26.4 & 53.9 & 33.9 & 57.7 \\
\hline $\begin{array}{l}\text { 2011(Agri- } \\
\text { Labourers) }\end{array}$ & 38.87 & 41.1 & 29.3 & 57.8 & 39.3 & 66.3 \\
\hline
\end{tabular}


Figure-2 All Agri-Labourers 2001-2011

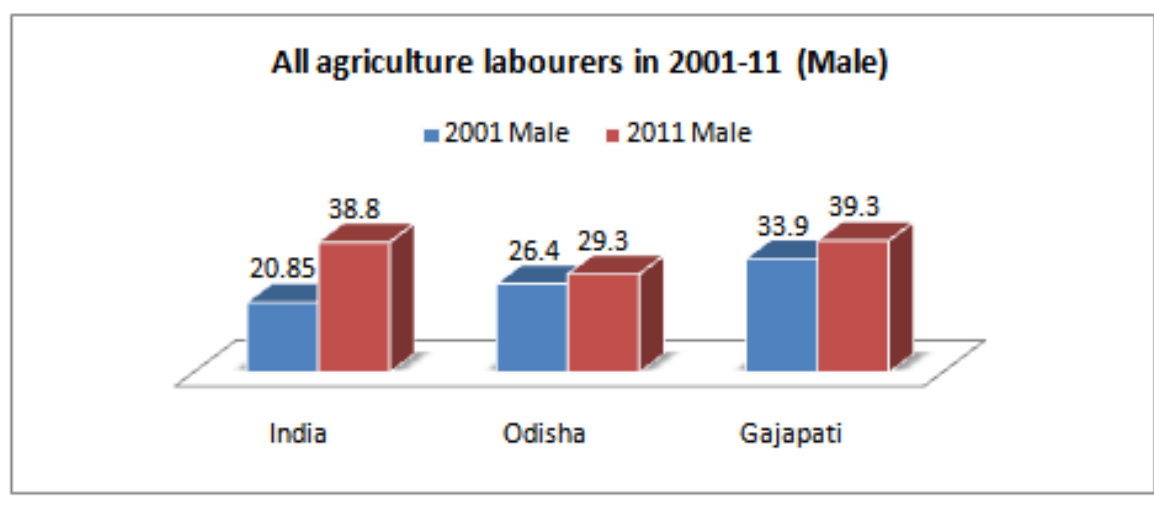

All agriculture labourers in 2001-11(Female)

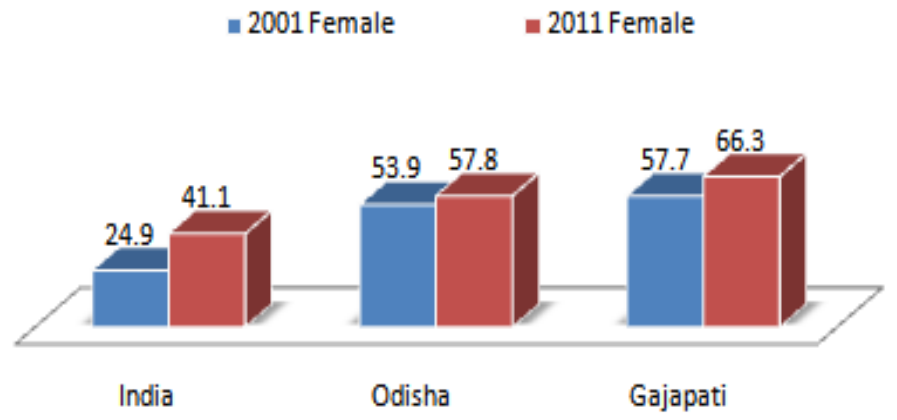

Table no- 1 shows the percentages of cultivators are decreased from 31.06 to 24.9 percent between 2001 to 2011 in India. The two trends are vary clearly visible from this table, firstly, the cultivators are declining and percentage of agricultural labourers are increasing between 2001 to 2011 in India. This shows more and more men are becoming pauper and losing their land. Among women, trend is same but the degree of pauperisation is vary deep around 25 percent of women who were engaged as agricultural labourers, their percentage has increased to 41 percent. More than 16 percent of increase is shown among women agricultural labourer at all India level. This shows more pauperisation among women in agrarian sector of the country. Similarly we observe 9 percent declining trend among women cultivators between 2001 to 2011 in India. While 6 percent men have lost their land; around 9 percent of women have lost their cultivated land. This shows more women have lost their position as cultivators than that of their cultivator men counterpart in the country. There is one important methodological issue to be remembered here that women cultivators do not have pattas in their names on agricultural their land it is either in the name of male members or in the family names. In the state of Odisha similarly the percentage of agricultural labourer are increased from 26.4 percent to 29.3 percent whereas this decline is more-deep in case of women. In the state of Odisha 53.9 percent women were engaged as agricultural labourer in 2001 which is increased to 57.8 percent in 2011 (See tab-2 \& fg-2). The Gender divide figure shows women are just the double percent than that of men who are engaged as agricultural labourer in the state. In comparison to men, the women are more marginalised in the state. While looking to the case of Gajapati (Table no- 1) much more women are engaged as agricultural labourer. i.e. 57.7 percent in 2001 which has increased to 66.3 in 2011. The women as agricultural labourer are more marginalised in the district of Gajapati than that of the state of Odisha and India. In Gajapati district the Soura tribe constitutes 50.78 percent as per 2011 census. Women constitute 54.86 percent of the total Soura population of the district. It is obvious to infer that more Saora women are engaged as agricultural-labourer than that of other tribe and general people of the district. These data analysis shows the marginalisation of Saora women as agricultural-labourer is acute. Among cultivators the position of women are vary weak in Gajapati district. As per 2001 census; around 27.5 percentages of women cultivators have lost their land and it has declined to 14 percent, which shows in Gajapati district half of women who had some short of land in their hand they lost in this decade. Similarly 37 percent of men who were cultivator in 2001 in Gajapati, that has declined to 29.6 percent to 17 percent have lost their land 
investigate and have become Agri-Labourer in this district. In the Odisha around 6 percent of men have lost their land and have hand become Agricultural Labourer. In case of women in Odisha around 7 percent have cultivator have lost their land. in all India case 6 percent men cultivator have lost their land and 9 percent of women cultivator have lost their land at all India level between 2001 to 2011 (See tab-1 \& fg-1). The Census data of 2001-2011 shows that total male worker percentage has slightly increase from $52 \%$ to $53 \%$ where as WWPR was very marginal constituting around $25.6 \% 2001$ which as slightly comedown to $25.5 \%$ in 2011 . This shows women constitute $50 \%$ less than that of male workforce. The worker participation rate of (WPR) India by sex between 2001-2011. Male worker constitute 52 percent in 2001. But which is increased to 53.3 percent in 2011. Women worker participation rate (WWPR) is very marginal i.e. 25.63 percent (2001), which has come down to 25.5 percent in (2011). Figure-1 shows WWPR is more than 53 percent less in comparison to MWPR. Clearly reveals that around two third i.e. $75 \%$ of women are Non-worker as per 2001-2011 Census. But women's work participation rate is very high as such to quote UN report; "women do two third of worlds work earn one third of income and own one hundredth part of world property". The data of our Table-1contdradict the UN report. In reality women do two third of world is work; but we here confront a methodological problem of defining workers. As per India Census, the paid persons are only counted as worker but women in our society work a lot and around 90 percent of them are not paid. Table-1 shows 74.5 percent women, 46.7 men of are Non-workers, which not meant that 75 percent women are certainly not working. On the other hand all women are working women; but most of them are unpaid workers at home. India census need to change its definition of worker, unpaid worker. As per the present definition goes; there are very few women workers (25.5\%) and most of them are engaged as marginal workers. The gender discrimination in work participation rate, paid women worker are 50 percent less than that of men worker. The figure of non-worker table clearly reveals women are at a very disadvantage state.In Odisha WPR shows the similarly result 52 percent of men were engaged in some worker other in to 2001 which as increased slightly (3.6\%) and as reached 56 percent during 2001. But WPR for Odisha is at very low stage. Only 24.7 percent of women were engaged in some worker other around 2001, which as slightly increased $(2.5 \%)$ and reached 27.2 percent in the year 2011. These shows WWPR are just half the percentage of men worker's participation rate. Non-worker among men were 47.5 percent in to 2001 where as non-worker were 75.3 percent. In the same year Odisha the shows more than $2 / 3$ percent of women in Odisha are not engaged any type of paid work nearly half of male population (47.5\%) were not engaged in any type of paid work.

Table. No-2

\begin{tabular}{|c|c|c|c|c|}
\hline & \multicolumn{2}{|c|}{$\begin{array}{c}\text { Worker and Non-Worker in Gajapati } \\
2001\end{array}$} & \multicolumn{2}{c|}{$\begin{array}{c}\text { Worker and Non-Worker in } \\
\text { Gajapati 2011 }\end{array}$} \\
\hline & Worker & Non-Worker & Worker & Non-Worker \\
\hline Male & 56.6 & 43.4 & 55.1 & 44.9 \\
\hline Female & 49.7 & 50.6 & 46.8 & 53.2 \\
\hline
\end{tabular}

(Source: Census of India 2011 final data, Registrar General of India), Databook for PC: ${ }^{\mathrm{TH}}$ Aug-2014. Census of India 2011, Primary Census Abstract Figure at a Glance and Data Highlight.

Figure No-2

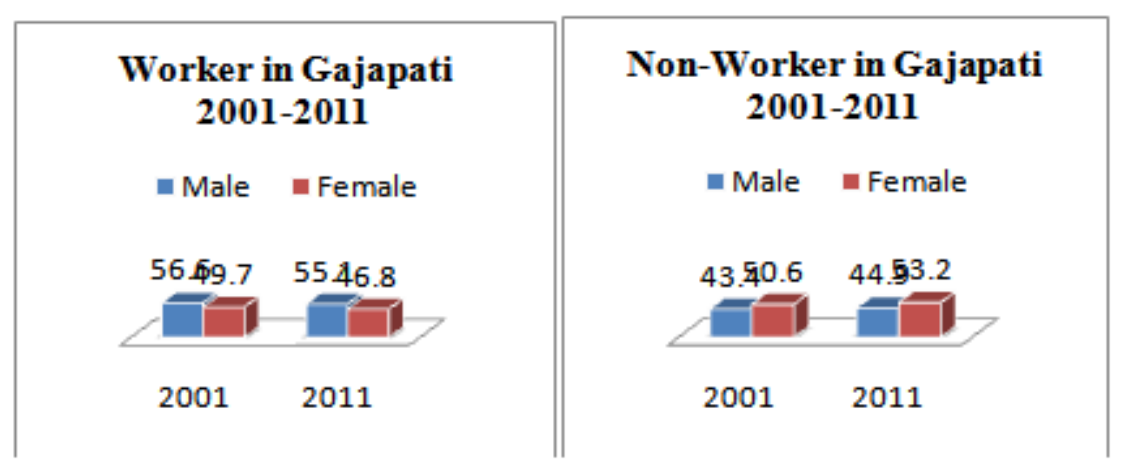

In Gajapati district we find Women constitute $50 \%$ of the workforce where as men constitute $57 \%$ of the total workers. Among non-worker women are more (50.6) in comparison to men (43.4). This is trending all India, all Odisha level also. But same how 50\% WWPR shows a significant highest of Women Work Participation Rate (WWPR) in Gajapati district. May be due to high concentration \% of tribal population are engaged as marginal worker for their own survival. This is a marginal status of tribal women in Gajapati district. Which will be further clarified while stratify women engaged in Agrarian sector (See figure-2). Marginalisation of women are 
clearly revelled in table. Marginal workers are as high as 42.7 percent in 2001, which has slightly being reduce to 40.2 percent in 2011. Whereas among men marginal workers are as low as 12.6 percent of in 2001 in India. This as slightly increased to 17.7 percent of 2011 in our country. While looking at the gender divide data among marginal workers we find more than 40 percent of women worker are working as marginal labourer. Whereas only 18 percent of men are working as marginal labourer in our country as per Census 2011 . In Odisha the story is more precarious among women marginal workers which ' is as high as 66.1 percent as per 2011 census. Even the marginalisation of women as increased from 64.6 percent of in 2001 to 66.1 percent of in 2011. Among men the marginal workers were as low as 18.3 percent of in 2001, but this is as increased 18.1 percent to 26.1 percent in 2011. The marginalisation both among men and women increase in the state of Odisha; but this as been consciously high increase of women.

Table. No.3-Main and Marginal in Gajapati 2001-2011

\begin{tabular}{|c|c|c|c|c|}
\hline & \multicolumn{2}{|c|}{ Main and Marginal in Gajapati 2001 } & \multicolumn{2}{c|}{ Main and Marginal in Gajapati 2011 } \\
\hline & Main Worker & $\begin{array}{c}\text { Marginal } \\
\text { Worker }\end{array}$ & Main Worker & $\begin{array}{c}\text { Marginal } \\
\text { Worker }\end{array}$ \\
\hline Male & $\mathbf{8 0 . 6}$ & $\mathbf{1 9 . 4}$ & $\mathbf{7 1 . 5}$ & $\mathbf{2 8 . 5}$ \\
\hline Female & $\mathbf{4 8 . 5}$ & $\mathbf{5 1 . 5}$ & $\mathbf{4 2 . 7}$ & $\mathbf{5 7 . 3}$ \\
\hline
\end{tabular}

Source: Census of India, 2011 primary census abstract figure at a glance Odisha Figure No-3-Main and Marginal in Gajapati 2001-2011

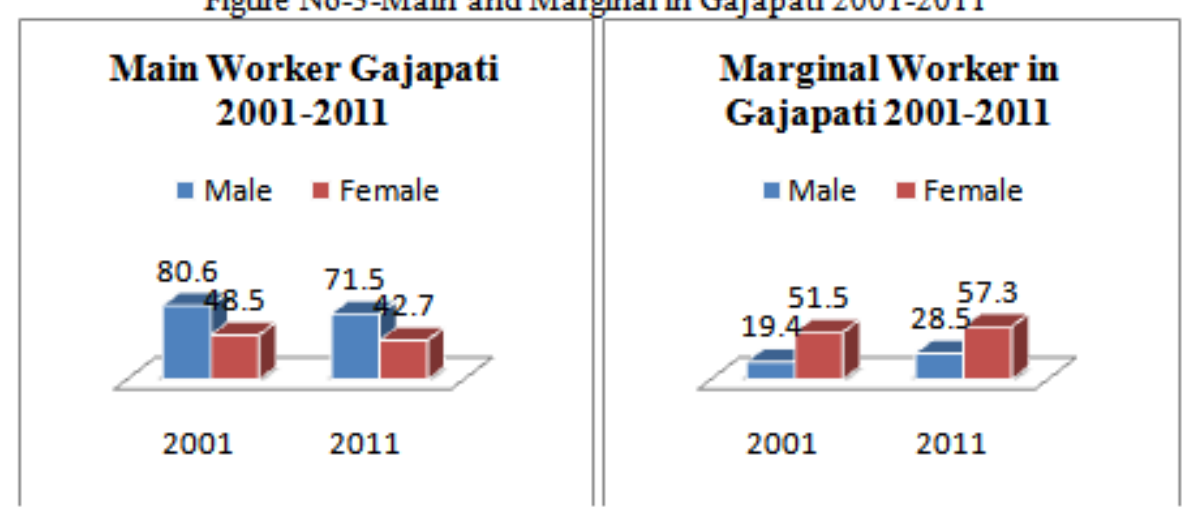

In Gajapati district the marginalisation among women is as high as 51.5 percent this as increased 5.8 percent from 2001 to 2011. As the tribal women are engaged in all the type of agricultural work in comparison to their counter parts in postal district. Main worker among women is as is around 43 percent of in the district in comparison to 71.5 percent of men who are engaged in Gajapati district. But men worker among women as decline from 48.5 percent to 42.7 percent in 2011. Marginal worker among men as been increased from 19.4 percent to 28.5 percent in 2011. But marginalisation among in the district is all as high then the men (See tab$3 \& \mathrm{fg}-3)$.Agriculture is that enterprise where a large proportion of female agricultural workers is directly engaged and plays a very significant role. Recent studies highlight that women in India are the major of food in terms of value, volume and number of hours worked. According to the NSSO data, in 2004-05, in rural areas about 83 per cent women workers were engaged in agriculture, either as cultivators or as laborers, as compared to 63 per cent of male workers. Although a significant proportion of the rural workers are engaged in agriculture, but they are able to get work for only a few months of the year. This keeps them employed only in the "subsidiary status."(Goswami and Bordoloi: 2013). Women clearly have a central role to play in boosting agricultural productivity and economic development in rural communities (Dijkstra T: 2001). Many of the Sauras were in a food gathering economy and a few were perhaps on the threshold of a real food producing economy and production items Mango, Banana, Lemon, Orange, Pineapple etc. Two of the sampled families have converted the dry land provided by the State into fields suitable for cultivation of paddy. The Sabaras in their villages do not use any standard agricultural methods for cultivation. Shifting cultivation is the way of life for the tribals and so to say it is the main occupation of the sabars. This types of cultivation known as "podu" locally is operated on the slopes of the nearly hills. The area of podu land per family ranges from 1.5 to 4.5 acres. On podu land mainly maize locally known as 'jonna' is cultivated, which is their staple food. They grow another varieties 'Kandul, jhodunga. The nature of the agriculture being practiced by the tribal households is not technology intensive, rather labour intensive. The Sauras of the plains depend on their wet cultivation or wage earning and selling firewood and the Hill Sauras practice shifting and terraced cultivation on the hill slopes. Collection firewood is the main occupation of the Sabara or Saura women which provides them minimum 
sustenance throughout the year. Both men and women collect firewood but the collection of Mahua flowers is done exclusively by women and children. Mahua flowers are mainly stored for preparation of wine throughout the year only if there is any surplus it is exchanged for eatables and household purchases. In all these works women rather than men take active part and contribute substantially in the family income (Sarma, P. R: 1990). Besides routine household work, the tribal women work in the agricultural fields, forests for long hours. The overall output if seen in terms of number of hours of work is low. Their schedule of long working hours continues even during pregnancy, natal and postnatal stages. They have a negative energy balance, high morbidity rate, and low child survival rate. They suffer from taboos and superstitions and remain deprived of the benefits from existing development and welfare programmes (Naresh,Gummdi: 2014).Reflects The general work participation rate of men and women between 2001 to 2011. Table shows participation of workers by sex in Gajapati district in 2001. Total work participation rate among men and women is quite closer that is $52 \%$ and $48 \%$ respectively. In rural area of Gajapati district, $51 \%$ of men are workers and $49 \%$ of women are workers. But in urban area $75 \%$ of men and $25 \%$ female are total respectively in 2011 . Within Gajapati district more women are engaged as workers in rural area in comparison to urban area. Nearly $20 \%$ less women in urban area are not working. If we see the agricultural labourer in total, women (60.6) are much more than men (39.31). In rural area $61 \%$ women are agriculture labourer and 5\% are agriculture labourer in urban area. Among men the 36.9\% of agriculture labourer are much is $39 \%$ same table shows among cultivators men are higher in number than women. Nearly $60 \%$ of men are cultivators in rural Gajapati and $70 \%$ cultivators are in urban Gajapati. Whereas $40 \%$ of women cultivators are in rural Gajapati and $30 \%$ of women are cultivators in urban Gajapati. This clearly reveals women are more marginalised in agrarian sector of Gajapati district.

Table-4-All STs Percentage Distribution of Workers in Four Economic Categories, Odisha

\begin{tabular}{|l|l|l|l|l|l|l|l|l|l|}
\hline $\begin{array}{l}\text { Economic } \\
\text { Category }\end{array}$ & $\begin{array}{l}\text { All } \\
\text { STs } \\
\text { Odisha }\end{array}$ & Khond & Gond & Santal & Kolha & Munda & Saora & Shabar & Bhottada \\
\hline Cultivators & 33.3 & 39.1 & 39.1 & 32.3 & 25.8 & 23.4 & 29.6 & 27.5 & 32.6 \\
\hline $\begin{array}{l}\text { Agri- } \\
\text { Lobourer }\end{array}$ & 46.9 & 46.8 & 46.6 & 45.1 & 47.6 & 41.7 & 54.3 & 55.3 & 58.2 \\
\hline $\begin{array}{l}\text { HHI } \\
\text { Workers }\end{array}$ & 4.8 & 3.6 & 3.3 & 9.3 & 7.9 & 5.3 & 2.8 & 1.4 & 0.7 \\
\hline $\begin{array}{l}\text { Other } \\
\text { Workers }\end{array}$ & 15 & 10.5 & 11 & 13.3 & 18.8 & 19.5 & 13.3 & 15.8 & 8.6 \\
\hline
\end{tabular}

Source: Office of the Registrar General, India, Data Highlights: The Scheduled Tribes Census of India 2001, Orissa.

Category of Workers: In Odisha agricultural labourers constitute the highest proportion i.e. 46.9 per cent among the total workers; this figure is higher than that of the national average of 36.9 per cent. 'Cultivators' accounts for 33.3 per cent which is lower than that of all Scheduled Tribes at the national level 44.7 per cent. 'Other Workers' constitute 15 per cent. This proportion is at par with that of the national average i.e. 16.3 per cent whereas workers engaged in Household Industry constitutes 4.8 per cent only, which is 2.7 per cent higher than that of all Scheduled Tribes at the national level. Among the major tribes, Bhottada, Shabar and Saora have more than half of the total workers who are agricultural labourers. Among the major groups, both Khond and Gond tribes have the highest share of cultivators, whereas Munda have the highest proportion of other workers. In the category of Household Industry, Santal holds the top position. These soura populations contribute to the four Economic Categories i.e. Cultivators 29.6 percent, Agricultural Labourer 54.3 percent, Household Industry Workers 2.8 percent only and Other Workers 13.3 percent. Agricultural related activities are picking and threshing of paddy crops followed by harvesting, winnowing, storage, making threshing yard, bagging/packing and marketing of agricultural produce. The roles of tribal farmwomen in all these operations were observed up to the highest importance level (Chayal and Dhaka, 2010). Agriculture production is dependent on rainfall (Hans Asha, 2014). Agricultural pattern in our study area is primarily based on hill cropping pattern. Mostly people go for the cultivation of Ragi, Corn, Janna as main crop in year. And for secondary crop almost all families go for Jhudunga, Kandula and Kulata. Mostly people go for kharif cultivation and very few people go for rabbi cultivation where these are mostly found in wet land area (joba khiari). There is no irrigation facility in our study area of Gajapati district, though the river Mahendra Tanaya is flowing in this district. The perusal of the data in regards to participation of tribal farm women in sowing operation revealed that the highest participation of tribal farmwomen was observed in sowing, transplanting followed by stubble collection, clod crushing and seedbed preparation (Chauhan, N. M. \& Thakor, R, 2006). Our study area among men 77 per cent 
are agricultural farmers and 23 per cent are wage labourers. From among our women respondents 97 per cent are daily worker and $3 \%$ are housewives. But these daily wage workers among women also constitute agricultural workers.Our study are reflects that very few families are doing multi crop cultivation i.e. around $13 \%$. Nearly $87 \%$ are depending on their single crop cultivation which is a very poor source of earning. Cash cropping in our study area are such as Mango, Banana, Cashew, Lemon, Orange, Jackfruit and Pineapple cash crop. The cash crops in the area are mainly citrus fruits, Cashew, Mango and Orange etc.

Summary: The focus of the cultivation undertaken by the tribal households is twofold, either to cultivate food grains for self-consumption or cultivate produce for the market, especially vegetables. Fruit bearing trees (Mango, Citrus, Jackfruit, Banana, Papaya, and Cashew) are grown inside forests, common lands or on homestead lands. However, it is seen that there is tendency to grow rice either on ancestral lands or sharecropping farms, because they are more fertile and suitable for rice cultivation. Millets are grown more on 'Padar' lands. Vegetables are cultivated on abandoned or bonded high lands. Most of the vegetables produced are sold in the local markets and in nearby towns. They perform on a daily basis the most tedious and backbreaking tasks in agriculture, animal husbandry and homes. They are invariable paid lower wages than men for the agricultural labour. Land ownership titles are most often in a man's name. The Sauras of the plains depend on their wet cultivation or wage earning and selling firewood and the Hill Sauras practice shifting and terraced cultivation on the hill slopes. Collection firewood is the main occupation of the Sabara or Saura women which provides them minimum sustenance throughout the year. Both men and women collect firewood but the collection of Mahua flowers is done exclusively by women and children. Mahua flowers are mainly stored for preparation of wine throughout the year only if there is any surplus it is exchanged for eatables and household purchases. In all these works women rather than men take active part and contribute substantially in the family income.

\section{REFERENCE:}

[1] Bosesrup, E., (1970), “Woman's Role in Economic Development”, New York: St. Martin’s Press.

[2] Burch, D., Lawrence, G., Green, G. P., Ichijo, K., Nonaka, I., Pimentel, M., ... \& Carneiro, M. J. (2007). World Development Report 2008: agriculture for development (No. E14 231). The World Bank..

[3] Census of India (2001) Office of the Registrar General, India, Data Highlights: The Scheduled Tribes Census of India 2001, Orissa.

[4] Census of India (2011) final data, Registrar General of India, Data book for PC: $4{ }^{\mathrm{TH}}$ Aug-2014. Census of India 2011, Primary Census Abstract Figure at a Glance India.

[5] Chauhan, N. M. (2012), "Role performance of tribal farm women in agricultural and animal husbandry in Gujarat" Karnataka Journal of Agricultural Sciences, 24(5).

[6] Chauhan, N. M., \& Thakor, R. (2006). Participation of the tribal farm women in decision making Gujarat J. Ext. Edu., Anand, 16, 55-57.

[7] Chayal, K., \& Dhaka, B. L. (2016). Analysis of role performance of women in farm activities. Indian Research Journal of Extension Education, 10(2), 109-112.

[8] DARE/ICAR Annual Report. (2003-4), “women in agriculture” New Delhi.

[9] Dijkstra, T. (2001). Export diversification in Uganda: developments in non-traditional agricultural exports.

[10] Doss, C. R., Grown, C., \& Deere, C. D. (2011). Gender and asset ownership: a guide to collecting individual-level data. World Bank Policy Research Working Paper Series, Vol.

[11] Food and Agriculture Organisation of the United Nation (FAO, 2011), the State of food and agriculture 2010-11, Women in Agriculture, (Rome: FAO, 2011).

[12] Food and Agriculture Organization of the United Nations (FAO, 2011), the Role of Women in Agriculture 2011. Available from: http://www.fao.org/docrep/013/ am307e/am307e00.pdf.

[13] Goswami, N., \& Bordoloi, A. K. (2013). Female Participation in Agriculture. Int. J. Basic Applied \& Social Sci, 1(1), 1-6.

[14] Haan and Dubey (2003), 'Poverty in Orissa: Divergent Trends? With Some Thoughts on Measurement Issues', Mimeo, Paper presented at the Workshop on 'Monitoring of Poverty in Orissa', 26-27 February, Nabakrushna Choudhury Center for Development Studies, Bhubaneswar.

[15] Hans Asha, (2014), "Scheduled Tribe Women of Odisha", Odish review, November-14, pp. 26-32, 27-40 $p d f$.

[16] Hans Asha, (2014), "Scheduled Tribe Women of Odisha”, Odish review, November-14, pp. 26-39, 27-40 $p d f$.

[17] Kumar, K. (2006). Dispossessed and displaced: A brief paper on tribal issues in Orissa. Co-Acting Monthly Review of the state and people, 1(1). 
[18] Mohanty, S.C. \& Paikaray, B.K. "Impact of Deforestation on Tribal Life and Livelihood: A case study of the Langia Saora or Saura”. Jurnal-ADIVASI, Vol- 49 Numb- 01, SCSTRTI, Bhubaneswar, Odisha.

[19] Naresh,Gummdi., (2014), "work participation of tribal women in india: a development perspective", IOSR journal of humanities and social science (IOSR-JHSS), Vol. 19, Issue 12, Ver. II, pp. 35-38. eISSN:2279-0837, p-2279-0845. www.iosrjournals.org

[20] Nigst, S., (2004). Gender Main streamlining world vision.

[21] Patel, Amrita. (2012) "Empowering Women in Agriculture" Yojana, June, vol-56, pg-20.

[22] Prasad, C., \& Singh, R. P. (1992). Farm women:“A Precious Resources” in Women in Agriculture, Vol. 2. Education, Training and Development edited by RK Punia.

[23] Raksha, J. C. (2016). Women: Seeds of Change in Agriculture. Indian Research Journal of Extension Education, 15(3), 72-79.

[24] Raksha, J. C. (2016). Women: Seeds of Change in Agriculture. Indian Research Journal of Extension Education, 15(3), 72-79.

[25] Sarma. P. R, (1990) "Relational Structure of Sabara Women: A Multiplex Network Analysis" ADIBASI, Scheduled Caste \& Scheduled Tribals Research and Training Institution (SCSTRTI), Bhubaneswar, Odisha Vol. XXX. No.1, pg-12-13. 